\title{
Extensor Indicis Brevis Muscle: A Case Report
}

\author{
Damtew Solomon' \\ Daniel Atlaw iD \\ Habtamu Gezahegn (iD ${ }^{2}$ \\ 'Anatomy Department, Madda Walabu \\ University, Bale Goba, Ethiopia; \\ ${ }^{2}$ Physiology Department, Madda Walabu \\ University, Bale Goba, Ethiopia
}

\begin{abstract}
Even though anatomical variations in the hand, involving muscles and their tendons are common, the majority of anomalous variations are asymptomatic throughout a lifetime. Such variations are commonly appreciated during surgical procedures involving the hand or during routine cadaver dissection. The index finger has two independent extensor tendons, and in some cases, has lower incidence of anomalous variations than other extensor tendons. We found muscular variant of extensor indicis proprius (EIP) during a cadaver dissection while teaching medical anatomy students at Addis Ababa University Black lion Specialized and Teaching Hospital, 2018. While dissecting of right hand of unknown age male cadaver, proper tendons attaching to the indicis finger are present and anomalous muscle, the so named extensor indicis brevis, was observed. The muscle originates from ulnar styloid process and inserted as a single tendon to the base of proximal phalanx of index finger. Attention is needed during surgical procedures like tendon reconstruction because anatomical variation of EIB may affect a surgical procedure.
\end{abstract}

Keywords: extensor indicis brevis muscle, variation

\section{Introduction}

During routine cadaver dissection procedures, variations of hand muscles and tendons are commonly observed. Such variations can be discovered incidentally during surgical procedures or during routine dissection. However, these variations are rarely associated with clinical significance, especially when the variant muscle occupies the narrow dorsal compartments of the wrist. Hence, it is important to expect the existence of muscular variations of the hand. During reconstructive surgeries of the dorsum of the hand, it is mandatory to expect such muscular variant. ${ }^{1}$

Extensor indicis brevis muscle (EIB) is variant muscle that is found on the dorsum of the hand and it is slightly dominant among males. This muscle is found in approximately $2 \%$ to $3 \%$ of the population which may be easily mistaken for other dorsal hand pathology. ${ }^{2,3}$

\section{Materials and Methods}

The case report involved routine dissection of unknown age male cadaver. The dissection of upper limb carried out in the Department of Anatomy of Black Lion Specialized and Teaching Hospital, Addis Ababa, Ethiopia, 2018. Skin and superficial fascia was removed, the dorsum of the hand was exposed to look for variant muscle origin, insertion, action and its neuro vascular supply. The so named EIB muscle was followed from its origin to its insertion. Other nearby structures were thoroughly observed to detect variation. An elastic tape measure was used to measure the length and thickness of variant muscle. Fresh cadaver, which was preserved by injection of formalin ( $10 \%$ formalin) based preservative, was dissected during first year medical anatomy course.
Correspondence: Damtew Solomon Anatomy Department, Madda Walabu University, PO Box 302, Bale Goba, Ethiopia

Tel +251920023076

Email fraolsolomon675@gmail.com 


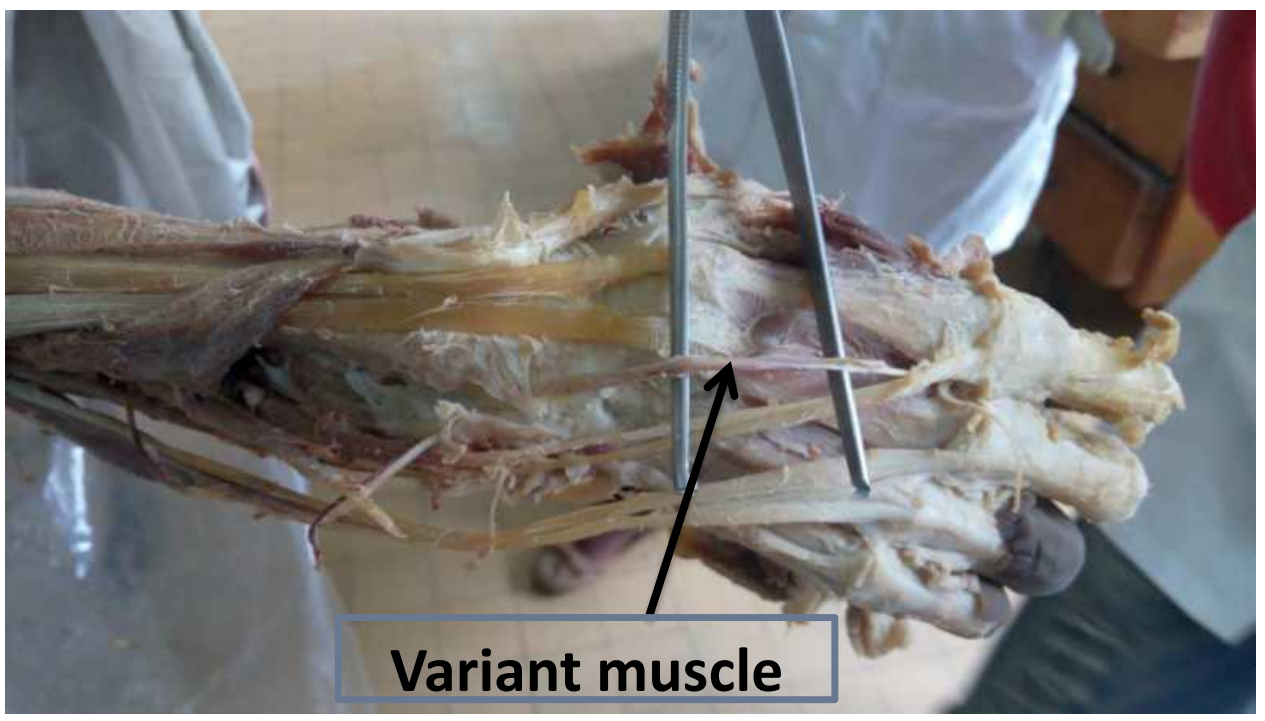

Figure I Photograph of the extensor indicis brevis muscle taken from right hand of male cadaver at Black lion Hospital, Addis Ababa, Ethiopia, 20 I8.

\section{Results}

Routine anatomical dissection of the right upper extremity of an anonymous-aged and formaldehyde-fixed cadaver at Black Lion Specialized and Teaching Hospital for 1st year medical students (Figure 1).

Ethiopian male cadaver, from department of Anatomy at Black Lion Specialized and Teaching Hospital, muscular variation was observed (Figure 1). Skin and superficial fascia was removed, the dorsum of the hand was exposed to look for variant muscle origin, insertion, action and it neuro vascular supply. The variant muscle originates from ulnar styloid process and inserted as a single tendon to base of proximal phalanx of index finger. The action of the variant muscle is extension of index finger at metacarpo phalengeal joint (MPJ). Belly of the muscle was fusiform and it was innervated by small branches of radial nerve (posterior interosseous nerve). The blood supply was provided by the posterior interosseous artery.

\section{Discussion}

For interpretation of unusual presentation of musculoskeletal system, diagnosis and planning of surgical tendon transfer, it is important to understand anatomical variations. ${ }^{10}$ In our case report, which was found during routine cadaver dissection, we have found variant extensor indicis brevis (EIB) of single belly. The variant muscle measured about $4.1 \mathrm{~cm}$ long and $0.4 \mathrm{~cm}$ thick. Even though cases with two bellies of EIB have been reported, ${ }^{3}$ commonly the variant muscle has a single belly. ${ }^{4-6}$ Based on findings of different authors, different origin and insertion of EIB has been explained (Table 1).

Based on its insertion, Ogura et $\mathrm{al}^{7}$ classified this variant muscle into three types which includes Type I inserted onto the dorsal aponeurosis of index finger, Type II - inserted on the index finger and Type III - inserted on the long finger. In different clinical case reports, the EIB is commonly misdiagnosed as a dorsal wrist ganglion. ${ }^{4,5}$ In the case of Murakami and Todani, together with a dorsal wrist ganglion an EIB was found lying over the ganglion. ${ }^{5}$

In conclusion, knowledge of muscle variation is not only important for differential diagnosis but also for elimination of bad outcomes of surgical procedure. Therefore, EIB is a muscle structure that can present as variant on the dorsum of the hand which needs consideration in case of surgical intervention and during routine dissection.

\section{Abbreviations}

EIB, extensor indicis brevis; EIP, extensor indicis proprius; $\mathrm{M}$, male; MPJ, metacarpophalyngeal joint.

\section{Data Sharing Statement}

Any data used to support the findings of this study are available from the corresponding author upon request.

\section{Ethical Approval and Consent to Participate}

Ethical approval for the study was obtained from Addis Ababa University, Black Lion Specialized and Teaching Hospital, Anatomy Department. The hospital secured the 
Table I Showing Comparison of Origin and Insertion of Variant Extensor Indicis Brevis Muscle of Different Authors

\begin{tabular}{|c|c|c|c|c|c|c|c|c|}
\hline Author & Origin & Insertion & Innervation & $\begin{array}{l}\text { Blood } \\
\text { Supply }\end{array}$ & $\begin{array}{l}\text { Dissected } \\
\text { Hand }\end{array}$ & $\begin{array}{l}\text { Length } \\
\text { in } \mathrm{cm}\end{array}$ & $\begin{array}{l}\text { Thickness } \\
\text { in } \mathbf{c m}\end{array}$ & Sex \\
\hline$\| l i e v$, et.al ${ }^{8}$ & $\begin{array}{l}\text { Joint capsule and } \\
\text { ligaments of } \\
\text { scaphoid and lunate } \\
\text { bones }\end{array}$ & $\begin{array}{l}\text { Ulnar side of the index } \\
\text { extensor digitorum } \\
\text { communis tendon }\end{array}$ & $\begin{array}{l}\text { Posterior } \\
\text { interosseous } \\
\text { nerve }\end{array}$ & $\begin{array}{l}\text { Posterior } \\
\text { interosseous } \\
\text { artery }\end{array}$ & Left & 4.4 & 0.55 & $M$ \\
\hline $\mathrm{Li}, \operatorname{Ren}^{9}$ & $\begin{array}{l}\text { Joint capsule } \\
\text { ligament }\end{array}$ & $\begin{array}{l}\text { Ulnar side of the } \\
\text { extensor digitorum } \\
\text { communisindex finger }\end{array}$ & $\begin{array}{l}\text { Posterior } \\
\text { interosseous } \\
\text { nerve }\end{array}$ & $\begin{array}{l}\text { Not } \\
\text { explained }\end{array}$ & Left & 3.6 & I.I & $M$ \\
\hline $\begin{array}{l}\text { Jing Li, } \\
\text { Zhen } \\
\text { Fengren }\end{array}$ & $\begin{array}{l}\text { Joint capsule and } \\
\text { ligaments of } \\
\text { scaphoid and lunate }\end{array}$ & $\begin{array}{l}\text { Single tendon to the ulnar } \\
\text { of index extensor } \\
\text { digitorum communis } \\
\text { tendon }\end{array}$ & $\begin{array}{l}\text { Posterior } \\
\text { interosseous } \\
\text { nerve }\end{array}$ & $\begin{array}{l}\text { Not } \\
\text { explained }\end{array}$ & Right & 4.6 & 0.75 & $M$ \\
\hline $\begin{array}{l}\text { Garbelotti } \\
\text { Junior, et.al }\end{array}$ & $\begin{array}{l}\text { Ligament and over } \\
\text { the scaphoideum } \\
\text { and trapezoideum }\end{array}$ & $\begin{array}{l}\text { Dorsal aponeurosis of the } \\
\text { indicis }\end{array}$ & $\begin{array}{l}\text { Not } \\
\text { explained }\end{array}$ & $\begin{array}{l}\text { Not } \\
\text { explained }\end{array}$ & Left & 6.6 & 2.1 & $M$ \\
\hline
\end{tabular}

written consent from families of cadaver, as it is involved for teaching and research purposes. Families of the cadaver also informed as the information obtained will be kept confidential.

\section{Acknowledgments}

We thank Addis Ababa University, Anatomy Department for their preparation and offering of fresh cadaver during our study stay.

\section{Disclosure}

The authors report no conflicts of interest in this work.

\section{References}

1. Cauldwell E, Anson B, Wright R. The extensor indicis proprius muscle. A study of 263 consecutive specimens. Quart Bull Northwestern Univ Med School. 1943;17:267-269.

2. Coudert X, Deghrar A, Lavarde G. Supernumerary muscle on the dorsal surface of the hand. A case report. Ann Chir Main Memb Super. 1993;12:230-232. doi:10.1016/s0753-9053(05)80108-5
3. Paraskevas G, Papaziogas B, Spanidou S, Papadopoulos A. Unusual variation of the extensor digitorum brevis manus: a case report. $J$ Eur Orthop Surg Traumatol. 2002;12:158-160. doi:10.1007/s00590-0020035-4

4. Macalister A. Additional observations on muscular anomalies in human anatomy (third series), with a catalogue of the principal muscular variations hitherto published. Trans Roy Irish Acad. $1875 ; 25: 1-130$.

5. Murakami Y, Todani K. The extensor indicis brevis muscle with an unusual ganglion. Clin Orthop Relat Res. 1982;162:207-209.

6. Fernandez Vazquez J, Linscheid R. Anomalous extensor muscles simulating dorsal wrist ganglion. Clin Orthop Relat Res. 1972;83:84-86. doi:10.1097/00003086-197203000-00014

7. Ogura T, Inoue H, Tanabe G. Anatomic and clinical studies of the extensor digitorum brevis manus. $J$ Hand Surg Am. 1987;12:100-107. doi:10.1016/S0363-5023(87)80171-5

8. Iliev A, Georgiev GP, Dimitrova IN, Landzhov B. Extensor indicis brevis muscle: anatomical and clinical considerations. Acta Morphol Anthropol. 2015;22:75-78.

9. Li J, Ren ZF. Bilateral extensor indicis brevis: a rare muscular variant. Rom J Morphol Embryol. 2012;53(1):185-187.

10. Garbelotti Junior S, Yukio Fukuda T, Rodrigues Pereira V, Garcia Lucareli P, Olave E. Extensor indicis brevis muscle: an unusual muscular variant. Int $J$ Morphol. 2012;30(3):1071-1073. doi:10.4067/S0717-95022012000300050

\section{Publish your work in this journal}

The International Medical Case Reports Journal is an international, peer-reviewed open-access journal publishing original case reports from all medical specialties. Previously unpublished medical posters are also accepted relating to any area of clinical or preclinical science. Submissions should not normally exceed 2,000 words or 4 published pages including figures, diagrams and references. The manuscript management system is completely online and includes a very quick and fair peer-review system, which is all easy to use. Visit http://www.dovepress.com/testimonials.php to read real quotes from published authors. 